\title{
PERILAKU PROSOSIAL ANAK USIA 5-6 TAHUN TERHADAP ANAK DOWN SYNDROME DI PAUD TAMAN BELIA CANDI SEMARANG TAHUN AJARAN 2016/2017
}

\author{
Anita Chandra Dewi \\ Universitas PGRI Semarang,Indopnesia \\ anitachandra@gmail.com \\ Erny Sofianni \\ Universitas PGRI Semarang,Indonesia \\ ernisofiani@gmail.com
}

\begin{abstract}
The purpose of this study was to describe the propocial behavior of children aged 5-6 years against down syndrome children in Early Childhood Taman Belia Candi Semarang Academic Year of 2016/2017. This type of research is descriptive qualitative research. This research subject is the principal, homeroom teacher, children aged 5-6 years and their parents. Descriptive qualitative research analysis result can be concluded that the prosocial behavior of children aged 5-6 years in accordance with a Standard Level of Achievement of Child Development, behavior of children with down syndrome have made progress when compared with the first entry in the school, and prosocial behavior of children aged 5-6 years against down syndrome children have been very visible and will become a habit so that the down syndrome child no longer needs special assistance but just need help from his friends.
\end{abstract}

Keywords : Children, Prosocial Behavior, Down Syndrome

\section{Abstrak}

Tujuan penelitian ini adalah untuk mendeskripsikan perilaku prososial anak usia 5-6 tahun terhadap anak down syndrome di PAUD Taman Belia Candi Semarang Tahun Ajaran 2016/2017. Jenis penelitian ini adalah penelitian kualitatif deskriptif. Subjek penelitian ini adalah kepala sekolah, wali kelas, guru, anak usia 5-6 tahun, dan orang tua. Hasil analisis penelitian kualitatif deskriptif dapat disimpulkan bahwa perilaku prososial anak usia 5-6 tahun telah sesuai dengan Standar Tingkat Pencapaian Perkembangan Anak (STPPA), perilaku anak down syndrome sudah mengalami kemajuan jika dibandingkan dengan pertama kali masuk di sekolah, serta perilaku prososial anak usia 5-6 tahun terhadap anak down syndrome sudah sangat terlihat dan akan dijadikan suatu kebiasaan sehingga anak down syndrome tidak lagi memerlukan pendampingan khusus melainkan hanya membutuhkan bantuan dari teman-temannya.

Kata Kunci : Anak, Perilaku Prososial, Down Syndrome 


\section{A. PENDAHULUAN}

Pendidikan bagi anak usia dini adalah pendidikan paling dasar yang mendapatkan posisi sangat strategis dan menguntungkan dalam pengembangan sumber daya manusia untuk menstimulasi, membimbing, mengasuh, dan memberikan kegiatan pembelajaran yang akan menghasilkan kemampuan dan ketrampilan anak.(Yuliana Sujono,2009:2). Anak usia dini memiliki kemampuan dan potensi besar yang masih harus dikembangkan dengan bantuan orang tua dan orang dewasa atau guru. Dimulai dari lingkungan keluarga yaitu orang tua atau pihak lain yang memang dekat dengan anak, guru diberbagai lembaga pendidikan harus memberikan layanan yang tepat dan seoptimal mungkin bagi anak usia dini.

Dalam dunia pendidikan, peran guru sangatlah penting. Guru bertanggung jawab untuk mengoptimalkan seluruh aspek perkembangan, mengontrol dan merespon perilaku anak. Salah satu aspek yang perlu dikembangkan yaitu sosial-emosional, karena aspek inilah yang dapat membekali anak untuk bergaul dan berinteraksi dengan teman dan lingkungannya.(Ika Puspasari ,2013::3) Kemampuan interaksi sosial pada anak merupakan suatu hal yang penting untuk dikembangkan sejak dini. Karena interaksi sosial anak sangat mempengaruhi tingkat perkembangan anak dari usia dini hingga usia dewasa. Interaksi sosial adalah kunci dari kehidupan sosial karena manusia hidup berdampingan dan bersamaan dengan manusia lainnya.( Soerjono Soekanto:1982) Begitu pula dengan anak, anak juga hidup berdampingan dengan teman sebayanya dan dengan lingkungan sekitarnya.

Interaksi sosial erat hubungannya dengan perilaku prososial. Pada interaksi sosial ini, perilaku prososial akan terjadi dikarenakan individu membutuhkan bantuan orang lain untuk memenuhi kebutuhan hidupnya. Dalam melakukan tindakan prososial, individu perlu menolong atau membantu untuk meringankan persoalan individu lain. Lebih pentingnya, perilaku prososial itu dilakukan secara sukarela dan bukan karena paksaan. (Nanda Setioasih : 2016)

Dalam penelitian ini, peneliti mencoba untuk memfokuskan pada perilaku prososial yang muncul pada anak usia dini, khususnya pada anak usia 5-6 tahun. Penting bagi anak usia dini untuk bersosialisasi dengan lingkungannya, terlebih bersosialisasi dengan teman dalam lingkungan sekolahnya. Anak usia 5-6 tahun harus bisa bersosialisasi dengan semua teman sebayanya dengan baik, sopan, saling menghargai, bertoleransi, 
berbagi, dan tidak membeda-bedakan temannya (dalam Peraturan Menteri Pendidikan dan Kebudayaan Republik Indonesia Nomor 137 Tahun 2014 Tentang Standar Nasional Pendidikan Anak Usia Dini, Lampiran I : 28) antara teman yang normal dengan teman yang memerlukan kebutuhan lebih khusus, yaitu anak berkebutuhan khusus (ABK). Peneliti bermaksud ingin mengetahui perilaku prososial yang muncul pada anak usia 5-6 tahun terhadap $\mathrm{ABK}$ khususnya pada anak dengan gangguan down syndrome atau sindroma down.

Mencermati pendapat tersebut dan melihat kenyataan yang terjadi di lapangan tentunya ada rasa kekhawatiran, karena anak-anak masih belum bisa bermain, menghargai, toleransi, berbagi, bersikap kooperatif, serta bersikap sopan terhadap temannya yang memiliki gangguan down syndrome. Karena biasanya anak dengan gangguan down syndrome sering mendapat perlakuan yang tidak sama dengan anakanak normal lainnya, sering dijauhi temannya dengan alasan merasa takut berdekatan dengan anak tersebut, karena gampang memukul, menjambak rambut teman perempuannya, dan mendorong teman hingga jatuh, serta belum bisa diajak untuk bekerjasama dalam kelompok.Hal ini membuat peneliti melakukan penelitian mengenai perilaku prososial anak usia 5-6 tahun terhadap anak down syndrome di PAUD Taman Belia Candi Semarang.

Sesuai dengan latar belakang masalah di atas, maka fokus masalah dalam penelitian ini yaitu :

1. Bagaimanakah perilaku prososial anak usia 5-6 tahun di PAUD Taman Belia Candi Semarang?

2. Bagaimanakah perilaku anak down syndrome usia 5-6 tahun di PAUD Taman Belia Candi Semarang?

3. Bagaimanakah perilaku prososial anak usia 5-6 tahun terhadap anak down syndrome di PAUD Taman Belia Candi Semarang?"

Berdasarkan fokus masalah di atas, maka tujuan yang ingin dicapai dalam penelitian ini adalah untuk mendeskripsikan tentang :

1. Perilaku prososial anak usia 5-6 tahun di PAUD Taman Belia Candi Semarang.

2. Perilaku anak down syndrome di PAUD Taman Belia Candi Semarang.

3. Perilaku prososial anak usia 5-6 tahun terhadap anak down syndrome di PAUD Taman Belia Candi Semarang. 
Menurut Rushton, 1980 perilaku prososial berkisar dari tindakan altruisme yang tidak mementingkan diri sendiri atau tanpa pamrih sampai tindakan menolong yang sepenuhnya dimotivasi oleh kepentingan diri sendiri. Perilaku prososial adalah bagian dari kehidupan sehari-hari.( Sears dkk:1985.47)

Perilaku menolong dan altruisme merupakan pemberian pertolongan pada orang lain tanpa mengharap adanya keuntungan pada diri orang yang menolong. Perilaku prososial didefinisikan sebagai perilaku yang memiliki konsekuensi positif pada orang lain. Bentuk yang paling jelas dari prososial adalah perilaku menolong.(Faturochman:2006.74)

Menurut William, 1981 membatasi perilaku prososial secara lebih rinci sebagai perilaku yang memiliki intensi untuk mengubah keadaan fisik atau psikologis penerima bantuan dari kurang baik menjadi lebih baik, dalam arti secara material maupun psikologis.( Dayakisni dan Hudaniah :2009)

Sindroma down berasal dari kata down syndrome yang merupakan sekumpulan gejala gangguan yang disebabkan oleh penyimpangan kromosom nomor 21, yang berarti kromosom nomor 21 memiliki tiga genom. Gejala gangguan yang sering dinamakan Trisome 21 ini dikemukakan pertama kali oleh seorang dokter Inggris yang bernama Langdon Haydon Down pada tahun 1866.( Gunarhadi,:2005)

Sindroma down atau down syndrome merupakan suatu bentuk kelainan kromosom yang berdampak pada keterlambatan pertumbuhan fisik dan mental penyandangnya. Penyandang down syndrome pada saat itu sering disebut Mongoloid. Hal ini dikarenakan penyandang down syndrome memiliki ciri-ciri seperti orang Mongolia.( Olivia Duhita,:2013.4)

Down syndrome merupakan suatu kondisi keterbelakangan perkembangan fisik dan mental anak yang diakibatkan adanya abnormalitas perkembangan kromosom. Kromosom merupakan serat-serat khusus yang terdapat didalam setiap sel yang berada didalam tubuh manusia, dimana terdapat bahan-bahan genetik yang menentukan sifat seseorang.(Wiyani:2015) 


\section{B. KAJIAN TEORI}

\section{a. Pengertian Perilaku Prososial}

Perilaku prososial mencakup kategori yang lebih luas: meliputi segala bentuk tindakan yang dilakukan atau direncanakan untuk menolong orang lain, tanpa mempedulikan motif-motif si penolong. Menurut Rushton, 1980 perilaku prososial berkisar dari tindakan altruisme yang tidak mementingkan diri sendiri atau tanpa pamrih sampai tindakan menolong yang sepenuhnya dimotivasi oleh kepentingan diri sendiri. Perilaku prososial adalah bagian dari kehidupan sehari-hari. Perilaku prososial menurut pendapat di atas yaitu tindakan yang dilakukan untuk menolong dan membantu orang lain tanpa pamrih.

Perilaku menolong dan altruisme merupakan pemberian pertolongan pada orang lain tanpa mengharap adanya keuntungan pada diri orang yang menolong. Perilaku prososial didefinisikan sebagai perilaku yang memiliki konsekuensi positif pada orang lain. Bentuk yang paling jelas dari prososial adalah perilaku menolong. Perilaku prososial dari definisi di atas yaitu pemberian pertolongan dan perlakuan positif lainnya tanpa mengharap adanya keuntungan pada orang yang menolong.

Perilaku prososial dapat dimengerti sebagai perilaku yang menguntungkan penerima, tetapi tidak memiliki keuntungan yang jelas bagi pelakunya (Staub, 1978; Baron \& Byrne, 1994). Menurut William, 1981 membatasi perilaku prososial secara lebih rinci sebagai perilaku yang memiliki intensi untuk mengubah keadaan fisik atau psikologis penerima bantuan dari kurang baik menjadi lebih baik, dalam arti secara material maupun psikologis. Dalam hal ini dapat dikatakan bahwa perilaku prososial bertujuan untuk membantu meningkatkan well being orang lain. Sehingga dapat dipahami bahwa perilaku prososial adalah perilaku menguntungkan yang akan diterima oleh orang yang ditolong tetapi belum tentu menguntungkan bagi orang yang sudah menolong.

Perilaku prososial merupakan salah satu bentuk perilaku yang muncul dalam kontak sosial. Watson, 1998 mendefinisikan perilaku prososial sebagai suatu tindakan yang memiliki konsekuensi positif bagi orang, tindakan menolong sepenuhnya yang dimotivasi oleh kepentingan sendiri tanpa mengharapkan sesuatu untuk dirinya. 
Tindakan prososial menuntut pengorbanan tinggi dari pelaku dan bersifat sukarela atau lebih ditunjukkan untuk menguntungkan orang lain daripada untuk mendapatkan imbalan materi. Dari pengertian di atas dapat dipahami bahwa perilaku prososial memiliki konsekuensi yang baik dan positif bagi orang lain. Penolong melakukannya dengan sukarela dan tidak mengharapkan imbalan.

Berdasarkan pengertian perilaku prososial yang dikemukakan oleh berbagai tokoh diatas dapat disimpulkan bahwa perilaku prososial merupakan tindakan menolong atau memberikan bantuan yang ditujukan untuk menguntungkan orang lain (tanpa mengharapkan imbalan) atau menguntungkan diri sendiri, dan tanpa ada unsur paksaan.

\section{b.Pengertian Down Syndrome}

Sindroma down berasal dari kata down syndrome yang merupakan sekumpulan gejala gangguan yang disebabkan oleh penyimpangan kromosom nomor 21, yang berarti kromosom nomor 21 memiliki tiga genom. Gejala gangguan yang sering dinamakan Trisome 21 ini dikemukakan pertama kali oleh seorang dokter Inggris yang bernama Langdon Haydon Down pada tahun 1866.

Sindroma down atau down syndrome merupakan suatu bentuk kelainan kromosom yang berdampak pada keterlambatan pertumbuhan fisik dan mental penyandangnya. Penyandang down syndrome pada saat itu sering disebut Mongoloid. Hal ini dikarenakan penyandang down syndrome memiliki ciri-ciri seperti orang Mongolia.

Down syndrome adalah suatu keadaan fisik yang disebabkan oleh mutasi gen ketika anak masih berada dalam kandungan. Ahli pertama yang mengidentifikasi gangguan ini adalah John Langdon Down. Mutasi yang terjadi adalah mutasi gen pada kromosom 21, yaitu adanya tambahan bagian pada kromosom tersebut. Down syndrome merupakan suatu kondisi keterbelakangan perkembangan fisik dan mental anak yang diakibatkan adanya abnormalitas perkembangan kromosom. Kromosom merupakan serat-serat khusus yang terdapat didalam setiap sel yang berada didalam tubuh manusia, dimana terdapat bahan-bahan genetik yang menentukan sifat seseorang (Wiyani, 2014 dalam Wijayanti, 2015:121). 
Abnormalitas kromosom yang biasa dikaitkan dengan retardasi mental adalah down syndrome. Gangguan down syndrome ini disebut juga "Mongolisme". Disebut demikian karena mata sipit dari anak yang menderita gangguan ini memberi kesan seperti orang Mongol (dalam Semiun, 2006:277).

Berdasarkan pengertian down syndrome yang telah dikemukakan oleh berbagai tokoh di atas dapat disimpulkan bahwa down syndrome merupakan suatu gangguan pada fisik dan mental disebabkan oleh mutasi gen yang terjadi pada kromosom 21. Dan dengan gangguan ini, penyandang down syndrome sering disebut juga sebagai orang Mongol karena memiliki ciri-ciri yang sama dengan mereka.

\section{METODE PENEITIAN}

Jenis penelitian yang digunakan adalah jenis penelitian kualitatif naturalistik , yaitu mendeskripsikan tentang perilaku prososial anak usia 5-6 tahun terhadap anak down syndrome di PAUD Taman Belia Candi Semarang secara alamiah. Metode penelitian kualitatif menurut Sugiono (2016:15) adalah metode yang berlandaskan pada filsafat postpositivisme, digunakan untuk meneliti pada kondisi obyek yang alamiah. Penelitian ini dimaksudkan untuk memberikan gambaran secara naratif atau dalam bentuk kata- kata, dan menggunakan pertimbangan ingin mendalami secara keseluruhann hubungan-hubungan yang ada dalam situasi sosial selanjutnya dapat menemukan hal-hal yang baru. Penelitian kualitatif menunjuk pada makna, kedalaman konsep, definisi, ciri, metafora, lambang dan deskripsi sesuatu.

Informan-informan yang dapat dijadikan responden dalam penelitian adalah : (1) Kepala Sekolah PAUD Taman Belia Candi Semarang, (2) Wali Kelas Orange, (3) Guru, (4) Orang Tua, (5) Anak.Dalam penelitian kualitatif, yang menjadi instrumen dalam penelitian adalah peneliti itu sendiri. Menurut Nasution dalam Sugiono (2014:60), menyatakan bahwa dalam penelitian kualitatif, tidak ada pilihan lain selain menjadikan peneliti sebagai instrumen utama dalam penelitian. Alasannya adalah segala sesuatunya belum mempunyai bentuk yang pasti.

Penelitian ini menggunakan jenis data kualitatif. Data kualitatif dapat diperoleh peneliti melalui wawancara, observasi, dan dokumentasi yang disajikan dalam bentuk kata-kata.Pengecekan keabsahan data dalam penelitian kualitatif dapat dilakukan dengan 
beberapa cara yaitu perpanjangan pengamatan, peningkatan ketekunan dalam peneltian, triangulasi, diskusi dengan teman sejawat, analisis kasus negatif, dan member check.

\section{HASIL PEMBAHASAN}

Hasil pembahasan berupa hasil analisis perilaku prososial anak usia 5-6 tahun terhadap anak down syndrome. Analisis data dalam perilaku prososial anak usia 5-6 tahun terhadap anak down syndrome meliputi bukti percakapan yang menunjukkan adanya perilaku prososial yang muncul pada anak usia 5-6 tahun terhadap anak down syndrome. Hasilnya sebagai berikut :

\section{Perilaku Prososial Anak Usia 5-6 Tahun di PAUD Taman Belia Candi Semarang}

Perilaku prososial anak usia 5-6 tahun dilatarbelakangi oleh keluarga yang berbeda. Ada orang tua dan keluarga yang terbiasa menanamkan dan memberi contoh kepada anak untuk dapat berperilaku prososial kepada orang lain, ada pula orang tua dan keluarga yang tidak terbiasa bahkan tidak terlalu peduli dengan perilaku prososial yang semestinya harus ditanamkan kepada anak dalam kehidupan sehari-hari. Sehingga, penting bagi Kepala Sekolah, Wali Kelas, dan Guru Sentra untuk selalu menanamkan perilaku-perilaku yang mencerminkan kepedulian dan toleransi kepada orang lain di lingkungan sekolah maupun di rumah.

Pentingnya penanaman perilaku peduli dan toleransi yang sudah dilakukan oleh pihak sekolah, menjadikan anak-anak usia 5-6 tahun di PAUD Taman Belia Candi Semarang sudah mampu menunjukkan perilaku prososialnya kepada teman. Hal ini nampak pada pengamatan yang peneliti lakukan. Perilaku prososial yang ditunjukkan anak usia 5-6 tahun meliputi : mereka mau bermain dengan teman-temannya, mampu menghargai satu sama lain, memberikan bantuan kepada orang lain, mampu mengajak temannya untuk berkomunikasi, dan mau berbagi dengan orang lain.

Berdasarkan dari hasil wawancara dari beberapa responden mengenai perilaku prososial anak usia 5-6 tahun di PAUD Taman Belia Candi Semarang, dapat dianalisa bahwa perilaku prososial menjadi suatu karakter yang melekat bagi anak-anak. Anakanak mampu melakukan banyak hal yang sesuai dengan tugas perkembangannya. Usia 5-6 tahun adalah usia paling tinggi di PAUD, maka perilaku prososial anak usia 5-6 tahun sudah bisa dikatakan baik dan sesuai dengan Standar Tingkat Pencapaian Perkembangan Anak (STPPA). 
Beberapa tokoh, seperti Clarke dan Batson, Twenge, Ciarocco, Baumeister, dan Bartels, memahami perilaku menolong sebagai bagian dari perilaku prososial yang merupakan konsep yang sifatnya lebih umum. Menurut Agus Rahman (2014:220) perilaku prososial adalah tindakan yang menguntungkan orang lain atau masyarakat secara umum. Jadi setiap orang berhak melakukan dan menerima perilaku prososial dalam keadaan apapun.

Dari beberapa penelitian (Sears, Feedman, \& Peplau, 1991) memperlihatkan dengan jelas bahwa anak akan membantu dan memberi lebih banyak bila mereka mendapat ganjaran karena melakukan perilaku prososial (dalam Anas, 2007:82). Hal ini peneliti jumpai pada saat melakukan observasi pada anak-anak kelas Orange. Anak-anak yang melakukan perilaku prososial sebelumnya telah dimotivasi oleh berbagai pihak, yaitu kepala sekolah, guru wali, guru sentra, dan juga orang tua. Dan setelah anak melakukan perilaku prososial, guru bisa memberikan reward dan pujian kepada anak tersebut.

Berdasarkan hasil wawancara dan observasi serta penguatan teori dari beberapa tokoh di atas, maka dapat ditarik kesimpulan bahwa perilaku prososial anak usia 5-6 tahun di PAUD Taman Belia Candi Semarang sudah baik dan sesuai dengan Standar Tingkat Pencapaian Perkembangan Anak (STPPA). Peneliti juga melakukan pengamatan secara langsung kegiatan pembelajaran di sentra dan lingkungan sekolah, jelas tampak adanya perilaku prososial anak usia 5-6 tahun di PAUD Taman Belia Candi Semarang. Setiap anak yang diamati oleh peneliti menunjukkan perilaku prososialnya. Mereka dapat bermain bersama teman-temannya, saling menghargai pendapat teman, dapat bekerja sama dengan teman, menolong teman yang memerlukan pertolongan, serta berbagi dengan teman dan guru.

Indikator pencapaian perilaku prososial yang muncul pada anak usia 5-6 tahun berdasarkan pengamatan, wawancara dan dokumentasi yang peneliti lakukan. Dan perilaku prososial yang muncul pada anak usia 5-6 tahun dapat peneliti analisis melalui tabel sebagai berikut :

Tabel 1.

Indikator Perilaku Prososial yang Muncul Pada Anak Usia 5-6 Tahun

\begin{tabular}{|c|c|c|}
\hline No & Indikator Perilaku Prososial & Contoh Perilaku Prososial \\
\hline 1 & $\begin{array}{l}\text { Dapat bermain dengan teman-teman } \\
\text { sebayanya. }\end{array}$ & $\begin{array}{l}\text { Anak merasa senang dapat bermain bersama teman- } \\
\text { temannya di sentra maupun di playground. }\end{array}$ \\
\hline
\end{tabular}




\begin{tabular}{|c|c|c|}
\hline 2 & $\begin{array}{l}\text { Mengetahui perasaan } \\
\text { merespon secara wajar. }\end{array}$ & $\begin{array}{l}\text { Anak-anak bertanya kepada temannya untuk memastikan } \\
\text { bahwa temannya tidak mengalami kesulitan. }\end{array}$ \\
\hline 3 & Dapat berbagi dengan teman dan orang lain. & $\begin{array}{l}\text { Ada anak yang membawa banyak makanan, lalu dia } \\
\text { menawarkan kepada temannya untuk mencicipi dan makan } \\
\text { bersama dengannya. }\end{array}$ \\
\hline 4 & $\begin{array}{l}\text { Mampu menghargai pendapat teman dan } \\
\text { orang lain. }\end{array}$ & $\begin{array}{l}\text { Anak mampu menghargai saat teman sedang } \\
\text { menyampaikan pendapat atau bercerita kepada guru. }\end{array}$ \\
\hline 5 & Dapat bersikap kooperatif dengan teman. & $\begin{array}{l}\text { Saat ada kegiatan yang melibatkan banyak anak dan } \\
\text { mengharuskan mereka untuk bekerja sama, maka anak akan } \\
\text { bekerja sama meskipun ada sedikit perbedaan pendapat } \\
\text { diantara mereka. }\end{array}$ \\
\hline 6 & $\begin{array}{l}\text { Senang menawarkan bantuan pada teman } \\
\text { atau guru. }\end{array}$ & $\begin{array}{l}\text { Melihat temannya kesulitan, mereka berinisiatif untuk } \\
\text { menawarkan bantuan. }\end{array}$ \\
\hline 7 & $\begin{array}{l}\text { Senang mengajak temannya } \text { untuk } \\
\text { berkomunikasi (secara dua arah). }\end{array}$ & $\begin{array}{l}\text { Anak selalu mengajak temannya untuk berkomunikasi dan } \\
\text { berdiskusi. }\end{array}$ \\
\hline 8 & $\begin{array}{l}\text { Peka untuk membantu orang lain yang } \\
\text { membutuhkan. }\end{array}$ & $\begin{array}{l}\text { Anak peka untuk memberikan bantuan pada teman, guru } \\
\text { maupun orang lain yang membutuhkan. }\end{array}$ \\
\hline 9 & $\begin{array}{l}\text { Mampu menerima perbedaan yang ada pada } \\
\text { teman. }\end{array}$ & $\begin{array}{l}\text { Anak mampu menerima perbedaan pada teman, seperti } \\
\text { perbedaan fisik maupun kebutuhan anak lain. }\end{array}$ \\
\hline 10 & $\begin{array}{l}\text { Mengucapkan terima kasih atas bantuan } \\
\text { yang diterima dari orang lain. }\end{array}$ & $\begin{array}{l}\text { Anak selalu mengucapkan terima kasih kepada setiap orang } \\
\text { yang membantunya. }\end{array}$ \\
\hline 11 & $\begin{array}{l}\text { Mengucapkan kata maaf bila melakukan } \\
\text { kesalahan pada orang lain. }\end{array}$ & $\begin{array}{l}\text { Anak berusaha mengucapkan kata maaf atas kesalahan } \\
\text { yang diperbuatnya kepada orang lain. }\end{array}$ \\
\hline 12 & $\begin{array}{l}\text { Bersikap sopan dan santun pada guru atau } \\
\text { orang lain. }\end{array}$ & $\begin{array}{l}\text { Anak mampu bersikap sopan dan santun kepada orang yang } \\
\text { lebih tua. }\end{array}$ \\
\hline 13 & $\begin{array}{l}\text { Mampu menghargai saat teman sedang } \\
\text { berbicara. }\end{array}$ & $\begin{array}{l}\text { Anak mampu memberikan kesempatan kepada teman untuk } \\
\text { berbicara dan menghargainya saat teman sedang berbicara. }\end{array}$ \\
\hline
\end{tabular}

\section{Perilaku Anak Down Syndrome di PAUD Taman Belia Candi Semarang}

Dari hasil pengamatan yang dilakukan oleh peneliti, perilaku anak down syndrome di PAUD Taman Belia Candi Semarang dapat berubah-ubah. Ketika berinteraksi dengan teman-temannya, anak down syndrome bisa menjadi anak yang ramah, tenang, dan bisa mengatur tubuhnya. Tetapi dalam waktu singkat dan dengan alasan tertentu, perilaku anak down syndrome berubah, seperti : menangis, tidak mau mendengarkan perkataan siapapun, menyakiti teman (memukul, menarik baju, dan mendorong). Perilaku anak down syndrome ini masih bisa terkontrol dengan adanya nasehat dan pengarahan dari orang terdekat, yaitu Kepala Sekolah, Wali Kelas, dan Guru Sentra.

Robert Ingall (1987) menyatakan bahwa anak-anak dimanapun dan belajar bahasa apapun ternyata melalui tahapan dan proses yang sama. Dapat dipastikan bahwa perolehan bahasa dan bicara itu sendiri merupakan bagian dari sifat biologis manusia. 
Hal ini terjadi pada anak down syndrome yang menjadi objek penelitian. Anak down syndrome tersebut mengalami kemajuan dalam menyampaikan perasaannya. Dia nampak ingin bercerita, dan mengungkapkan apa yang sudah dialaminya kepada guru sentra. Berulang kali peneliti mengamati hal tersebut, beberapa guru sentra tidak memahami apa yang disampaikan oleh anak down syndrome itu. Tetapi begitu menakjubkan, teman-teman dari anak down syndrome itu mampu mengerti dan memahami apa yang disampaikan anak down syndrome tersebut. Mereka memperhatikan gerak tubuh dan ekspresi dari anak down syndrome, dan hasilnya adalah mereka mampu menggambarkan maksud dari cerita temannya yang down syndrome itu.

Berdasarkan ruang lingkup identifikasi kebutuhan khusus anak down syndrome, Mark Selikowitz, dalam Rini Surjadi, 1996, dan David Werner, 2002 menyatakan bahwa perkembangan pribadi dan sosial merupakan bentuk perkembangan yang meliputi keterampilan menolong diri sendiri dan keterampilan sosial. Dalam hal ini, keterampilan menolong diri sendiri meliputi menyuap dengan tangan, minum dari cangkir, menggunakan toilet, dan menggunakan peralatan makan. Sedangkan keterampilan sosial antara lain reaksi yang tepat terhadap masyarakat, membedakan teman dengan orang asing, dan bermain secara kooperatif bersama anak-anak lain. Identifikasi yang telah dilakukan tokoh di atas menunjukkan bahwa anak down syndrome di PAUD Taman Belia Candi Semarang sudah dapat melakukan serangkaian perkembangan pribadi dan sosial. Anak down syndrome bisa menolong dirinya sendiri dan tidak membutuhkan bantuan secara khusus dari orang lain, hanya memerlukan pengarahan secara tepat dan benar. Anak down syndrome memiliki keterampilan sosial yang cukup baik serta memiliki perilaku prososial yang terlihat ketika anak down syndrome berinteraksi dengan teman-temannya.

Perilaku prososial yang muncul pada anak down syndrome, sebagai berikut :

a. Anak down syndrome bisa bermain bersama teman-teman sebayanya. Dia selalu merasa senang bermain dengan siapapun, terlebih teman perempuannya.

b. Anak down syndrome memberikan bantuan kepada teman, contohnya : anak down syndrome pernah membantu membawakan botol minum temannya yang tertinggal di sentra dan memberikan botol minum itu kepada temannya. 
c. Anak down syndrome berkomunikasi secara dua arah, contohnya : selalu mencoba untuk berkomunikasi dengan teman dan guru sentra, meskipun perkataannya tidak jelas.

d. Dan anak down syndrome dapat bersikap kooperatif dengan teman, contohnya : anak down syndrome pernah terlibat kerja sama dengan teman-temannya dalam permainan kelompok.

Hasil pemaparan dari informan, pengamatan peneliti dan teori dari beberapa tokoh di atas, dapat ditarik kesimpulan bahwa perilaku anak down syndrome sudah banyak terlihat kemajuannya. Anak down syndrome mulai mendengarkan dan mengerti perintah sederhana, mulai bisa menyampaikan suatu cerita meskipun ucapannya tidak jelas, sudah hampir satu tahun ini anak down syndrome tidak didampingi orang tuanya lagi pada saat kegiatan pembelajaran, dan untuk sekarang dia hanya perlu dibimbing dan diarahkan lebih lagi. Dan penelitian ini menunjukkan bahwa anak down syndrome tidak membutuhkan pendampingan khusus dari orang lain. Anak down syndrome bisa menolong dirinya, dan anak-anak usia 5-6 tahun juga dapat memberikan bantuannya kepada anak down syndrome. Serta pihak sekolah bisa lebih memberikan penguatan dan arahan kepada anak down syndrome.

\section{Perilaku Prososial Anak Usia 5-6 Tahun Terhadap Anak Down Syndrome di PAUD Taman Belia Candi Semarang}

Dari hasil pengamatan yang dilakukan oleh peneliti, perilaku prososial anak usia 5-6 tahun terhadap anak down syndrome di PAUD Taman Belia Candi Semarang dapat terlihat dalam berbagai kegiatan. Anak-anak usia 5-6 tahun menunjukkan perilaku prososialnya kepada anak down syndrome dengan cara mereka masing-masing. Ada anak yang memang sudah terbiasa dekat dan membantu anak down syndrome, ada anak yang hanya sekedar menyapa tetapi juga mengingatkan jika anak down syndrome melakukan hal-hal yang mengganggu temannya, dan ada anak yang menyadari bahwa mereka harus membantu dan menerima keberadaan anak down syndrome. Mereka menyadari bahwa anak down syndrome memerlukan bantuan dan perhatian dari mereka. Sehingga, anak down syndrome tidak mendapati kesusahan saat beraktivitas serta tidak memerlukan pendampingan khusus dari guru. 
Menurut Cassidy, dkk, 2003 anak yang berperilaku prososial akan lebih sering menerima perilaku prososial dari orang lain dan anak yang mengembangkan perilaku prososialnya sejak dini cenderung untuk memiliki banyak teman dan lebih disukai. Beberapa anak pada usia 5-6 tahun sudah terbiasa menawarkan bantuan kepada temantemannya yang lain, bersikap baik kepada semua orang, dan mampu untuk menerima perbedaan yang ada pada setiap anak. Anak yang sudah melakukan kebaikan kepada orang lain, maka orang lain juga akan melakukan kebaikan pula kepada anak tersebut.

Hal di atas bisa diartikan sebagai hubungan timbal balik atau hubungan yang saling menguntungkan. Beberapa penelitian (Berkowitz, 1968; Wilke \& Lanzetta, 1970) menunjukkan bahwa orang lebih cenderung membantu seseorang yang pernah membantu mereka. Hasil penelitian dari tokoh tersebut juga peneliti temukan pada anakanak usia 5-6 tahun di PAUD Taman Belia Candi Semarang. Mereka akan melakukan hubungan timbal balik, dan hal tersebut menguntungkan bagi mereka. Terkait dengan perilaku prososialnya terhadap anak down syndrome, mereka sudah dinyatakan mampu dan terbiasa untuk membantu anak down syndrome, meskipun belum secara optimal dan sukarela karena masih harus dimotivasi dan diarahkan oleh Guru Sentra, Wali Kelas, dan juga Kepala Sekolah. Hasil pemaparan dari informan, pengamatan peneliti dan penguatan teori dari tokoh di atas, dapat ditarik kesimpulan bahwa perilaku prososial anak usia 5-6 tahun terhadap anak down syndrome sudah sangat terlihat bahkan sudah diterapkan dan menjadi suatu kebiasaan yang harus dilakukan oleh anak-anak usia 5-6 tahun. Mereka berusaha untuk mengerti keadaan temannya yang down syndrome, dan yang terpenting adalah mereka mau menerima keberadaan anak down syndrome tersebut. Hal ini juga membuktikan bahwa anak down syndrome sebenarnya tidak memerlukan guru pendamping atau pendampingan khusus saat pembelajaran. Anak down syndrome tersebut mampu mengatur dan mengontrol perilakunya, asalkan tetap diarahkan. Anak down syndrome memiliki kemajuan yang cukup baik dalam hubungan interaksi kepada teman-teman kelasnya. Sehingga, anak-anak usia 5-6 tahun bisa lebih bisa lebih menghargai, dan saling menerima kondisi dan perbedaan teman-temannya. 


\section{E. SIMPULAN}

Dari pembahasan ndi atas dapat di tarik kesimpulan bahwa ,Perilaku Prososial Anak Usia 5-6 Tahun di PAUD Taman Belia Candi Semarang: anak bisa memiliki banyak teman karena aksi perilaku prososialnya, anak-anak usia 5-6 tahun di PAUD Taman Belia Candi Semarang sudah memiliki perilaku prososial yang baik dan sesuai dengan Standar Tingkat PencapaianPerkembanganAnak (STPPA). Perilaku Anak Down Syndrome di PAUD Taman Belia Candi Semarang: perilaku anak down syndrome di PAUD Taman Belia Candi Semarang sudah sangat terlihat kemajuannya jika dibandingkan ketika awal mula dia masuk dan bersekolah di PAUD Taman Belia Candi Semarang, anak down syndrome di PAUD Taman Belia Candi Semarang tidak memerlukan bantuan dan pendampingan khusus dari guru, karena dengan adanya perilaku prososial dari teman-temannya akan sangat membantu aktivitas dari anak down syndrome. Perilaku Prososial Anak Usia 5-6 Tahun Terhadap Anak Down Syndrome di PAUD Taman Belia Candi Semarang: anak-anak saling menghargai dan juga membantu anak down syndrome dalam beraktivitas, meskipun hal tersebut juga dipengaruhi oleh adanya motivasi dari guru, wali kelas dan kepala sekolah tetapi mereka melakukannya dengan senang hati dan tanpa paksaan dari pihak manapun.

F. SARAN

Bagi Anak Didik:

a. Anak didik harus diarahkan agar bisa peka dan mengerti untuk berperilaku prososial terhadap anak down syndrome tanpa merasa takut dan cemas akan timbal baliknya yang didapat setelah melakukan aksi perilaku prososial kepada anak down syndrome.

b. Anak down syndrome harus diarahkan agar bisa belajar mandiri dan tidak bergantung kepada orang lain.

Bagi Orang Tua

a. Orang tua diharapkan agar ikut berpartipasi dalam menggerakkan aksi perilaku prososial pada anak dalam kehidupan sehari-hari.

b. Orang tua dari anak down syndrome harus bekerja sama dengan pihak sekolah untuk mengetahui perkembangan serta memberikan penanganan yang sesuai dengan kebutuhan anak down syndrome. 


\section{Bagi Sekolah}

a. Pihak sekolah perlu melatih guru PAUD untuk dapat memotivasi anak didik memiliki perilaku prososial kepada semua orang terutama kepada anak down syndrome.

b. Guru sebagai orang terdekat pada saat pembelajaran juga harus lebih bisa meningkatkan kesabaran dalam mengarahkan dan membantu anak down syndrome, sehingga anak down syndrome bisa mendapatkan perlakuan yang sama dengan anak normal lainnya. Hal ini disarankan supaya anak down syndrome bisa belajar untuk mandiri dan tidak bergantung kepada orang lain.

c. Guru harus menentukan kegiatan atau permainan yang lebih bisa memunculkan ide atau gagasan agar mereka bisa melakukan aksi perilaku prososial secara spontan dan sukarela.

\section{DAFTAR PUSTAKA}

Dayakisni dan Hudaniah. (2009.) Psikologi Sosial. Malang: UMM Press.

Duhita, Olivia. (2013). Cahaya Hidupku. Jakarta: Dian Rakyat.

Faturochman. (2006). Pengantar Psikologi Sosial. Yogyakarta: Pustaka.

Gunarhadi. (2005). Penanganan Anak Sindroma Down Dalam Lingkungan Keluarga dan Sekolah. Jakarta: Departemen Pendidikan Nasional.

Hapsari, Iriani. (2016). Psikologi Perkembangan Anak. Jakarta: Indeks.

Kemis dan Rosnawati. (2013). Pendidikan Anak Berkebutuhan Khusus Tunagrahita. Jakarta: Luxima Metro Media.

PeraturanMenteriPendidikandanKebudayaanRepublik Indonesia Nomor 137 Tahun 2014 TentangStandarNasionalPendidikanAnakUsiaDiniPasal 7 Tentang Standar Tingkat Pencapaian Perkembangan Anak Usia Dini ( STPPA).

Puspasari, Ika. (2013). Upaya Mengembangkan Kemampuan Interaksi Sosial Anak Melalui Pembelajaran Kooperatif Pada Anak Kelompok A Di TK Pertiwi Segaran Delanggu Klaten Tahun Ajaran 2012/2013. Naskah Publikasi (tidak diterbitkan). Surakarta: Universitas Muhammadiyah Surakarta.

Rahman, Agus. (2014.) Psikologi Sosial: Integrasi Pengetahuan Wahyu dan Pengetahuan Empirik. Jakarta: PT Raja Grafindo Persada. 
Sears, dkk. (1985). Psikologi Sosial. Jakarta: Erlangga.

Setioasih, Nanda.(2016.) Hubungan Antara Perkembangan Moral Dengan Perilaku Prososial Pada Remaja. Skripsi (tidak diterbitkan). Malang: Universitas Muhammadiah Malang.

Soekanto, Soerjono.( 1982). Sosiologi Suatu Pengantar. Jakarta: CV. Rajawali.

Sugiyono.( 2014). Memahami Penelitian Kualitatif. Bandung: Alfabeta.

Sugiyono. (2016). MetodePenelitianPendidikan (PendekatanKuantitatif, Kualitatif, dan $R \& D)$. Bandung: Alfabeta.

Sujiono, Yuliani. (2009). Konsep Dasar Anak Usia Dini. Jakarta: Indeks.

Wijayanti, Dian.( 2015). Subjective Well-Being Dan Penerimaan Diri Ibu Yang Memiliki Anak Down. Vol. 04, Nomor 01 ISSN: 0000- 0000. Diunduh pada tanggal 18 Desember 2016 Pukul 10.41 WIB. 